\title{
ETNODIALEKTOLOOGILINE UURIMUS VIIE PIIRKONNA ÕPILASTE MURDETUNDMISEST
}

\author{
SIIM ANTSO
}

\begin{abstract}
Annotatsioon. Artikkel käsitleb Kuressaare, Jõhvi, Pärnu-Jaagupi, Tartu ja Võru õpilaste murdetundmist. Selleks koguti andmeid etnodialektoloogilise kujutluskaardi katsega, milles õpilastel paluti kaardile märkida kõik neile tuntud murdealad. Artiklis analüüsitakse kõrvutavalt nii seda, milliseid murdeid õpilased nimetasid, kui ka seda, kuidas nad kaardil murrete levikuala kujutasid. Katse tulemustest selgus, et seos elukoha ja murdetundmise vahel on küll olemas, kuid ilmneb pigem tendentsidena. Nii näiteks märkisid Lääne-Eesti õpilased rohkem saarte murderühma murrakuid, Lõuna-Eesti õpilased aga rohkem Setu ja ka Mulgi murret. Siiski olid igas piirkonnas kaks enim märgitud murret saarte ja Võru murre, ehkki ilmnes ka erinevusi. Võru murde puhul erinesid eeskätt Saaremaa ja mandril elavate õpilaste vastused, saarte murret märkisid aga teistest oluliselt erinevalt Võru õpilased.
\end{abstract}

Võtmesõnad: eesti keel, eesti murded, etnodialektoloogia, sotsiolingvistika, kujutluskaardid

\section{Sissejuhatus}

Erinevuste märkamine eri piirkondade elanike kõnes on ikka ja jälle tekitanud inimestes tahtmise keelt ja murdeid piiritleda. Keeleteadlased on teinud seda eksplitsiitsete meetoditega, valdavalt on Eesti - ja maailma dialektoloogia huvi keskmes olnud murdekeele struktuur, mis on võetud ka murdealade eristamise aluseks. Samas on juba Eesti süstemaatilise murdeteaduse algusaastatel olnud huvi ka murdeteadlikkuse vastu. Nii on Andrus Saareste (1932: 35) Eesti murdeliigendust käsitlevas artiklis kirjutanud:

„Jääks nüüd selgitada, missugune on nende tuummaastikkude, nendes kõneldud murrakute iseloom? Kas kõneldakse neist igaühes naabrusest enam-vähem erineva, iseendas aga ühtlase ilmega murret, mille 
eksistentsist kõnelejaskond ja kuulajaskondki on kuidagi teadlikud? Viimase, psühholoogilise momendi tähtsus ses küsimuses pole väike. Seda tuleb siin arvestada samal määral, nagu segakeeltegi puhul ja kahe keele siirdmurrete kuuluvuse määramisel [..].“

Kuigi huvi selle probleemi vastu oli olemas, ei ole Eestis neid andmeid süstemaatiliselt siiski kogutud. Pakilisem ülesanne oli 1920.-1930. aastatel võimalikult palju koguda murdekeelt säilitamiseks. Seetõttu ei ole ka võimalik analüüsida, mida arvas toona näiteks võrulane saarlaste murdepruugist ja kuidas oleks ta oma ja võõrast murdeala piiritlenud.

Selle artikli eesmärk on anda esmane ülevaade sellest, kuidas tunnevad Eesti noored murdeid tänapäeval. Artikkel põhineb magistritööl (Antso 2015), kus analüüsisin etnodialektoloogilisest vaatenurgast viie Eesti piirkonna õpilaste murdetundmist. Etnodialektoloogias ei keskenduta mitte kõneleja keelejoonte kogumisele ega analüüsimisele, vaid uuritakse, mida ta teab ja ütleb (või ütlemata jätab) oma kodukoha ning ka ümbritsevate murdealade kohta. Üks levinum etnodialektoloogiline katse on lasta katseisikul joonistada murdekaart. Sellise katse korraldasin ka magistritöö jaoks ning saadud andmete põhjal koostasin statistiliselt üldistatud murdekaardid, mis näitavad, mis murdeid ja kuidas õpilased kaardile paigutasid.

Artikli esimeses osas annan ülevaate etnodialektoloogia mõistestikust ja teooriast. Teises osas käsitlen lähemalt kujutluskaartide meetodit, mille abil etnodialektoloogilisi andmeid kogutakse. Seejärel vaatlen eraldi iga piirkonna katsetulemusi. Esitan piirkonniti nii andmed õpilaste nimetatud murrete kohta kui ka üldistatud kujutluskaardid enim märgitud murrete põhjal. Püüan ka analüüsida võimalikke põhjuseid, miks õpilased just neid murdeid niimoodi märkisid, lõpuks kõrvutan piirkondade andmeid. Etnodialektoloogilises uurimistöös on ilmnenud üldine seaduspära, et elukoht mõjutab oluliselt murdetundmist. Sellepärast püüan artiklis leida piirkondi kõrvutades vastuse ka küsimusele, kas õpilased tunnevad lähemaid murdeid paremini kui kaugemaid.

\section{Etnodialektoloogia mõiste}

Etnodialektoloogias - tuntud ka kui tajudialektoloogia (ingl perceptual dialectology) - analüüsitakse tavakõnelejate murdehinnanguid ja -taju ning ka üldisemalt inimeste suhtumist keele geograafilisse varieerumisse 
(Preston 1999: xxv). Seega uuritakse etnodialektoloogilistes töödes keelt kultuuriliste, käitumuslike ja ühiskondlike tegurite mõju taustal. Etnodialektoloogia üks nimekamaid uurijaid Dennis R. Preston (1989: 14-21), kelle töödest lähtuvad pea kõik teised tänapäeva samaainelised uurimused, ühendas oma meetodis elemente nii traditsioonilisest dialektoloogiast, sotsiolingvistikast kui ka kultuurigeograafiast. Prestoni meetodi kõige viljakam ja uudsem osa küllap ongi kultuurigeograafiast tuntud kujutluskaartide (ingl mental maps) kasutamine, lastes katseisikutel märkida kaardile kõik neile tuntud murdealad (Preston 1999: xxxiv). Nendest katsetest selgub, kuidas mingi keele või murde kõnelejad ümbritsevat (või ka kaugemat) keelemaastikku liigendavad, ja seegi, mida katsealune peab murdeks ja mida mitte. Murdeks liigitamine näitab normikeele ning normist kõrvale kalduva keelekuju eristamist: mõlema kohta on inimestel omad hinnangud, väärtused ja stereotüübid. Normikeelt (näiteks riigi- või ühiskeelt) peavad kõnelejad enamasti korrektseks ning üldjuhul ei tunne selle kõnelejad mis tahes olukorras keelelist ebakindlust (st nad ei tunne end suhtluses teise inimesega alaväärsena). Normikeelest erinevate keelekujude kõnelejad võivad aga tunda end alaväärsena, kui nad vestlevad normikeelt kõneleva inimesega, kuna vestlusolukorra võimusuhe soosib sel juhul valdavalt normikeele kõnelejat. Mõistagi võib see võimusuhe muutuda, kui normikeele kõneleja jääb ümbritsevas keelekeskkonnas ise vähemusse. Normikeele kõnelejad rõhutavad eeskätt oma keele korrektsust, normikeelest erinevate keelekujude kõnelejad aga pigem oma keele meeldivust (nt sõbralikkust vastukaaluks normikeele külmusele). (Niedzielski, Preston 2000: 44; Preston 1999: xxxiv) Inimese keelekasutus ei näita vaid seda, kuidas ta kõneleb, vaid sellega käivad kaasas mitmed stereotüübid, mida kasutatakse inimese käitumise, välimuse või isiksuseomaduste (ülepaisutatud) üldistusena. Inimene ei pruugi olla mingi murdekeelega tuttav ega kokku puutunud, vaid võib tunda seda just stereotüübi või karikatuuri järgi. Seetõttu on etnodialektoloogias selliseid karikatuure ja stereotüüpe suure tähelepanuga analüüsitud (nt hillbillies 'USA lõunaosariikide elanikud') (Niedzielski, Preston 2000: 57).

Seega mõjutavad inimese murdetaju ja -hinnanguid nii keelelised kui ka keelevälised tegurid. Inimene ise ei pruugi neid niimoodi eristada, vaid need tegurid võivad toimida ühtse tervikuna. Üks enim uuritud tegur etnodialektoloogias on kauguse ja teabe pöördvõrdeline seos: mida kaugemal inimene mingist murdealast elab, seda vähem ta selle kohta teab (Preston 
1999: xxxv). Kuid peale tegeliku kauguse mõjutab inimese keeleteadmisi ka mentaalne või emotsionaalne kaugus sellest murdealast. Nagu sotsiolingvistikas on ka etnodialektoloogias prestiižil oluline koht. Nii näiteks on etnodialektoloogilistes uurimustes leitud, et väga suure prestiižiga keelekuju levikut iseloomustab n-ö kiirgusefekt (ingl radiation efect): tavakõnelejad peavad tuntud murdealasid suuremaks, kui need tegelikult on (Fought 2002: 115). Sel moel võib tuntud murdeala nimi kui tähis levida kaugemale ja katta ka teisi murdeid, iseäranis kui need on sellega keeleliselt sarnased.

\section{Kujutluskaartide meetod}

Kultuurigeograafiast pärit meetodi järgi peegeldab kujutluskaart inimese arusaama sellest, kuidas teda ümbritsevas ruumis orienteeruda (Dictionary). Kujutluskaarti mõjutavad inimese varasemad kogemused ning nendest tulenevad arvamused ja hinnangud. Ruumiinfo, mille alusel inimene oma kujutluskaardi koostab, võib jagada kaheks: otseseks ja vahendatuks. Otsest infot saab inimene ise mingis kohas olles oma meelte abil; kaudset infot aga mingisuguse teise meediumi vahendusel (kaardid, ajalehed, televisioon, vestlused teiste inimestega jne), niisamuti oma meelte abil. Kuigi viimane kätkeb juba valimit terviklikust ruumiinfost, ei erine Roger M. Downsi ja David Stea sõnul otsese ja vahendatud informatsiooni omandamine ja töötlemine. Kognitiivselt erinevad on hoopis mitmesugused seosed ja assotsiatsioonid, mida mingi paik esile kutsub ning mis on ruumiga nõrgemini seotud. (Downs, Stea 1973: 23-24) Nendest teadmistest lähtudes ei ole objektide mõõtmed ja suunad kujutluskaardil samad, mis kartograafilistel kaartidel. Võrreldes kaht sama kaugel asuvat paika, tunduvad inimestele keskuses või selle läheduses asuvad alad lähemal. Niisamuti on olulised ja tuntud paigad kujutluskaartidel suuremad, kui nad tegelikult on, või täpsemini piiritletud ja kujutatud. (Downs, Stea 1973: 17-18) Kujutluskaarti iseloomustab lünklikkus: esindatud on ainult märgilised ja olulised objektid, millest inimene ruumis orienteerumisel juhindub. Downsi ja Stea sõnul kasutavad inimesed hulganisti n-ö konventsionaalseid ruumisümboleid, millest nad võib-olla ainult kuulu järgi on teadlikud. Niisamuti üldistab inimene kognitiivset ruumitaju: näiteks ühe slummi nägemisest võib piisata, et inimene hakkaks selle põhjal kõiki slumme ühtmoodi käsitama. (Downs, Stea 1973: 20) 
Kuid mitte ainult see, mida inimene otseselt või vahendatult kogeb, ei mõjuta tema kujutluskaarti. Uurimustes (Murray, Spencer 1979; Bell, Iong 2011) on leitud, et ka inimese joonistusoskusest oleneb kujutluskaardi detailsus. Seega on võimalik, et mõne inimese ruumitaju uurimine jääb puudulikuks, kuna uuritav lihtsalt ei suuda seda piisavalt täpselt paberile kanda, kuigi see võib olla sama detailne kui parema joonistusoskusega inimesel. Mõlemas viidatud joonistusoskuse uurimuses kasutasid autorid vabakäejoonistuse katset: inimestel paluti tühjale paberilehele joonistada mingi piirkonna kaart. Debra Murray ja Christopher Spenceri (1979: 391) sõnul mõjutab joonistusoskus inimeste kujutluskaartide erinevust ainult 10-25\%. Prestoni katse puhul aga ei tohiks joonistusoskus nii suureks takistuseks olla, sest inimesel palutakse lihtsalt murdeid märkida (nt ring joonistada), mistõttu peaks piisama kõige algelisemast joonistusoskusest.

Prestoni katsega võivad kaasneda aga teised probleemid. Prestoni katse puhul on oluline aluskaardi valik, kuna vahetu informatsioon, mis inimesel katse ajal silme ees on, mõjutab olulisel määral tema otsuseid. Esimestest katsetest saadud tagasiside põhjal tõdeb Preston kaht vastandlikku probleemi. Kui kaardil on mis tahes riigisisesed halduspiirid, seostab osa inimesi neid ka murdepiiridega. Ainult riigipiiriga kaart seevastu võib jätta katsealused nõutuks ning nad ei täidagi kaarti. Alternatiiviks pakub Preston linnade, jõgede või mägedega kaarti. (Preston 1989: 25) Aluskaartide mõju kujutluskaardile on kirjeldanud Alfred Lameli, Christoph Purschke ja Roland Kehrein (2008: 80-83). Nende tehtud katsest selgus, et reljeefkaart tekitas inimestes pigem segadust ning ei aidanud kohalike keelekujude lokaliseerimisele kaasa. Jõgede kaart on võrreldav tühja, üksnes riigipiiriga tähistatud kaardiga ning ei aita keelekujusid kuigipalju paremini paigustada ega aktiveeri keeleväliseid tegureid. Riigisisesed halduspiirid mõjutavad aga oluliselt inimese kujutluskaarti ning rõhutavad keeleküsimuse poliitilist mõõdet ja regionaalseid prototüüpe. Kui kaardil on suuremad linnad, märgitakse need kohaliku keelekuju prototüüpideks. Kui aga kaardil on hulk väiksemaid linnu, siis nende prototüüpseid keelealasid ei märgita. Seevastu teises, uuemas uurimuses on leitud, et inimeste kujutluskaardid on vägagi sarnased, olenemata sellest, kas neil on linnade kaart aluskaardiks või mitte (Braber 2015: 19-20). Aluskaardi valik sõltub seega lõppude lõpuks uurimuse eesmärgist. Kui eesmärgiks on võimalikult spontaansed vastused, soovitavad Lameli, Purschke ja Kehreini tühja, 
ainult riigipiiriga kaarti. Kui aga tahetakse, et inimene võimalikult täpselt keelekujusid lokaliseeriks, siis on parim aluskaart selline, millel on hulk väiksemaid linnu. (Lameli jt 2008: 80-81) Riigisiseste halduspiiridega kaartide kasutamise õigustuseks võib tuua aga seda, et ainult sel moel saab täie kindlusega analüüsida, kas inimene seostab murde- ja keelepiire halduspiiridega.

Üksikutest kaartidest tuleb koostada ühe inimrühma kujutluskaart, et oleks parem võrrelda piirkondi omavahel või hinnata mõne teise muutuja mõju tulemustele. Murdetajupiiride üldistamiseks hindas Preston visuaalselt üksikute piiride koondumist kimpudesse: mida rohkem üksikuid piire ühte kohta kokku langes, seda tugevam murdepiir seal oli. Meetodi poolest on see sama mis isoglosside põhjal murdealade piiritlemine (Preston isegi nimetab neid tajuisoglossideks). (Preston 1989: 26-27) Tänapäeval on uurimustes kasutatud aga märksa võimekamat tarkvara, mis on vabalt kättesaadav ja sobib igasuguste ruumiandmete töötlemiseks. GIS ehk geograafiline infosüsteem on tarkvara, millega saab ruumiandmeid kujutada, analüüsida ja töödelda (Suurna, Sisas 2010: 8). Oma uurimuses võtsin eeskujuks Chris Montgomery ja Philipp Stoeckle 2013. aasta artikli „Geographic information systems and perceptual dialectology: a method for processing draw-a-map data", kus autorid kasutasid programmi ArcGIS, et üksikutest kujutluskaartidest teha üldistusi ja neid analüüsida. Montgomery ja Stoeckle on kasutanud kaht visualiseerimis- ja analüüsimisvõimalust. Esiteks on nad kujutanud kuhjatud murdealade üleminekuid järkudena: erineva värviga on tähistatud see piirkond, mida näiteks märkis $40-50 \%$ ja 80-90\% küsitletutest (Montgomery, Stoeckle 2013: 64). Teiseks on nad kujutanud ja analüüsinud, kuhu kõige rohkem inimeste märgitud murdealade piire kokku langes ehk siis nn tajuisoglosse (Montgomery, Stoeckle 2013: 71). Olen kasutanud samu analüüsivahendeid, lisaks mõõdan oma uurimuses murdealade ja piirkondade omavahelisi kaugusi ning arvutan piirjoonte keskmisi ning traditsioonilise keeleteadusliku ja tajutava murdeala kattumise protsenti.

Katsetulemused annavad informatsiooni nii murrete paiknemise kui ka hinnangute kohta. Hinnangud väljenduvad kahel tasandil. Esiteks selles, kas mingit piirkondlikku keelekuju normi- või oma keelest piisavalt erinevaks pidada, et seda murdeks nimetada. Teiseks ilmneb, kuidas märgitud piirkonna keelt on nimetatud või kommenteeritud. Võimalusi nimetamiseks on mõistagi mitmeid: nii neutraalseid (ilmakaared, kohanimed, 
haldusalad, keeleteadusterminid) kui ka hinnangulisi, mis rõhutavad kultuurilis-lingvistilisi ja regionaalseid stereotüüpe.

Arvatavasti võib mõnele inimesele murrete märkimine tähendada teadmist erinevusest, kuid mitte ilmtingimata keeleteadmisi. Üks võimalus selle uurimiseks on lisada kujutluskaartide ülesandele murrete tuvastamise katse, milles inimesel palutakse kaardile märkida, kust üks või teine murdekõne katkend pärit võiks olla. Hans Ladegaardi (2006: 177) hinnangul võimaldab see eristada, milliseid murdeid inimene kognitiivselt eristab. Ühtlasi on selle katse tulemustel sama alus ning vastused paremini võrreldavad. Natalie Braber (2015: 18-22) tegi 17-18aastaste õpilastega katse, kus ta palus neil helikatkendi põhjal arvata, mis piirkonna aktsent kõnelejal on. Braberi sõnul ei suutnud õpilased kuigi täpselt aktsente identifitseerida. Erandiks olid Liverpooli, Newcastle'i, Birminghami ja Walesi keelekujud, kuna Braberi sõnul on need piirkonnad kultuuris ja meedias märksa rohkem esil kui teised. Prestoni hinnangul olekski üks etnodialektoloogia arenemisvõimalusi selles, et hakataks rohkem ja eraldi uurima keelelisi jooni kui stiimuleid, mis mingi murde taju põhjustavad. Üheks selliseks võimaluseks pakub ta uurida murdekõne imiteerimist ning keele- või kõnenäidete paigutamist kaardile. (Preston 1999: xxxviii)

\section{Etnodialektoloogiline murdealade analüüs}

Uurimuse jaoks kogusin andmeid viiest piirkonnast: Kuressaarest, Jõhvist, Pärnu-Jaagupist, Tartust ja Võrust. Igas piirkonnas palusin gümnaasiumiõpilastel (sündinud 1993-1998) kihelkonnapiiride ja suuremate linnadega kaardile märkida kõik murdealad, mida nad teavad. Õpilased peaksid moodustama küllaltki ühtlase katserühma. Põhikoolis on nad juba õppinud Eesti murdeid ning on eeldatavasti murretega ka isiklikult (või vahendatult) vähem või rohkem kokku puutunud. Seega peaks neil olema erinevatest allikatest piisavalt teadmisi, et koostada murrete kujutluskaart. Iga piirkonda käsitlevas alapeatükis kirjeldan kõige sagedamini nimetatud murdeid ja esitan need kaardil. Lõpus võrdlen kõikide piirkondade murdealasid, et kinnitada või lükata ümber eespool kirjeldatud kauguse ja teabe pöördvõrdelise seose hüpotees. 


\subsection{Kuressaare vastused}

Kuressaare vastuseid oli 28. Kõik vastanud olid pärit Saaremaalt ning kõigi nende emakeel oli eesti keel. Keskmiselt märgiti Kuressaares 2,5 traditsioonilist (keeleteaduslikult määratud) kohamurret või -murrakut ankeedi kohta standardhälbega 1,6. Kõik märgitud murded ${ }^{1}$ koos nende osakaaluga on esitatud tabelis 1 .

Tabel 1. Kuressaare õpilaste märgitud murrete osakaal \%

\begin{tabular}{|l|c|}
\hline Murre & Osakaal \% \\
\hline Saarte & 82 \\
\hline Võru & 46 \\
\hline Hiiu & 21 \\
\hline Muhu & 18 \\
\hline Kihnu & 14 \\
\hline Setu & 14 \\
\hline Ruhnu & 7 \\
\hline Sorrve & 7 \\
\hline Harjumaa & 1 \\
\hline
\end{tabular}

Neli murret või murrakut, mida märkis vähemalt $15 \%$ vastanutest ${ }^{2}$, on saarte, Võru, Hiiu ja Muhu. Nende murdealade protsentuaalne ulatus on esitatud kaardil 1.

Saarte murde tuumala paikneb Saaremaal. Võru murde tuum jääb Rõuge kihelkonda. Hiiu ja Muhu murraku tuum katab samuti tervet saart. Paremaks üldistamiseks on kaardil 2 kujutatud iga murde puhul piirkond, mida vähemalt 50\% seda murret märkinutest tähistas.

Lähtudes sellest kaardist, katab Kuressaare õpilaste märgitud Võru murdeala umbes 34\% samast traditsioonilisest (keeleteaduslikult määratud) murdealast. Saarte murre piirdub kaardil 2 Saaremaaga ning katab seega ligikaudu $68 \%$ samast traditsioonilisest murdealast. Umbes $10 \%$ õpilasi märkis Hiiumaa saartemurdeliseks ning 30-40\% saarte murret märkinud õpilaste arvates kõneldakse ka Muhul saarte murret. Eraldi Muhu murrak jääb õpilaste vastustes Muhu saarele, niisamuti nagu Hiiu murrak vaid Hiiumaale.

1 Olen tabelites ja kaartidel jätnud murded ja murrakud eristamata, kuna ankeediski oli küsitud vaid murrete kohta.

2 15\% lävendi valisin Prestoni eeskujul. Mõistagi on see küllaltki meelevaldne. 


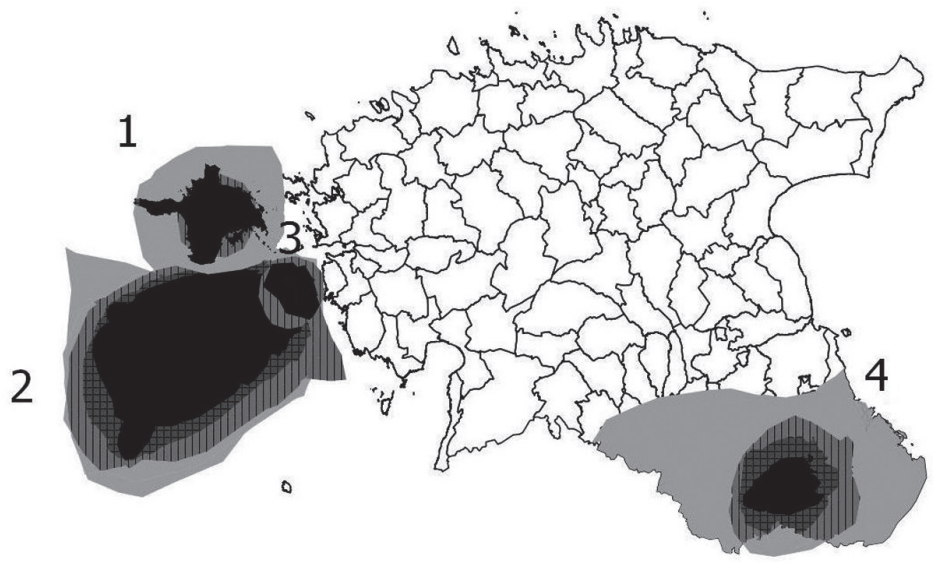

1. Hiiu murrak 2. Saarte murre 3. Muhu murrak 4. Võru murre

\begin{tabular}{|lccc}
$1-25 \%$ & $1-25 \%$ & $1-25 \%$ & $1-25 \%$ \\
$25-50 \%$ & $25-50 \%$ & $25-50 \%$ & $25-50 \%$ \\
$50-75 \%$ & $50-75 \%$ & $50-75 \%$ & $50-75 \%$ \\
$75-100 \%$ & $-75-100 \%$ & $75-100 \%$ & $75-100 \%$ \\
\hline-110
\end{tabular}

Kaart 1. Kuressaare õpilaste enim märgitud murrete ulatus \%

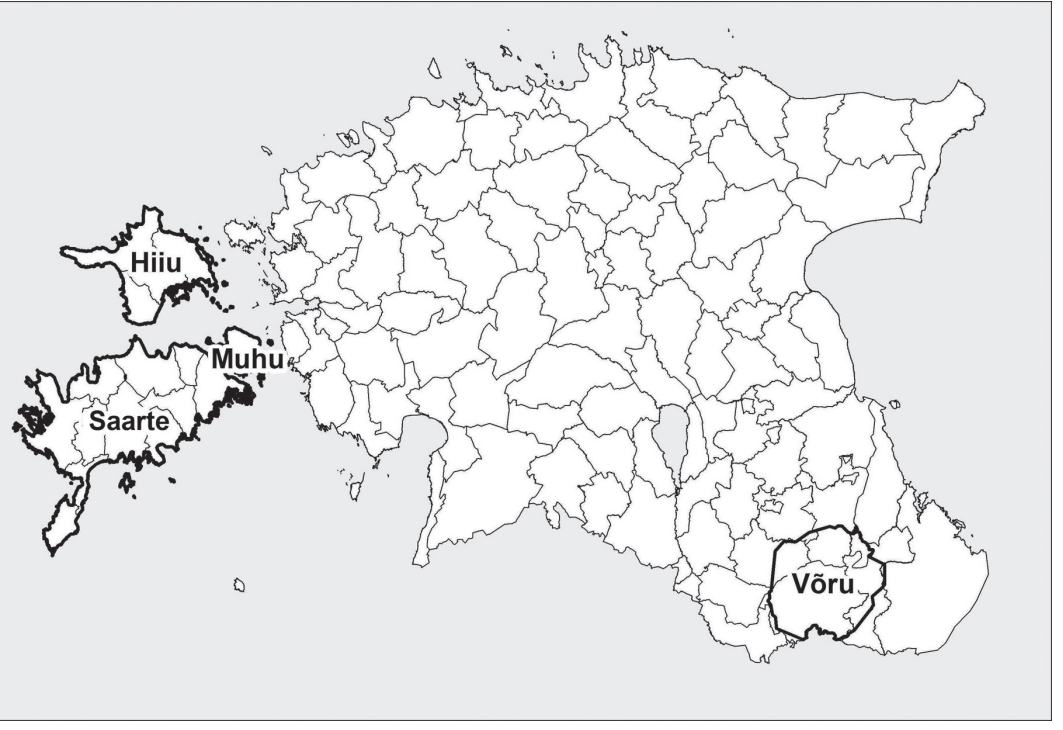

Kaart 2. Kuressaare õpilaste enim märgitud murded 50\% üksmeele korral 
Kaardil 1 on näha, et eri saarte puhul katab õpilaste märgitud piirkond suurematki ala kui ainult saare pind. Saart ümbritsevate vete arvamist murdeala hulka on üsna tõenäoliselt põhjustanud tagasihoidlikum joonistusoskus: saare kontuuride täpse järgimise asemel on õpilasele lihtsam olnud saart ja ümbritsevat piirkonda ringjoonega märkida. Kuid ka vastupidist on märgata: tervet saart ei ole ringiga ümbritsetud, nagu oli näha ka tuumalade kirjeldamisel. Mõistagi võis siingi mõju avaldada joonistusoskus, ent paaril korral oli vastustes näha, et see oli teadlik valik (nt saarte ja Sõrve murde/keele eristamine). Oleks väär seda teisteski vastustes pelgalt joonistusoskusega põhjendada: nendeski ankeetides võis õpilane tahta näidata, kus täpsemini näiteks Saaremaal saarte murret räägitakse, kus mitte. Õigem olekski seda pidada ikkagi tajutavate murdepiiride kaalutletud väljenduseks, mitte ebatäpseks märkimiseks. Sellest hoolimata tuleb tunnistada asjaolu, et praeguse andmestiku põhjal pole iga kord võimalik eristada teadlikku valikut ja ebatäpset märkimist.

Murdenimetustena kasutati vaid üks kord maakonnanime (Harjumaa). Ruumiandmetega kooskõlas oli saarte murde nimetamine ainsusliku täiendiga saare murdeks, kuna valdavalt piirduski see murre vaid ühe saarega (Saaremaa). Kahes ankeedis kasutati terminit „murrak“: Saare murrak, Seto murrak, ning ühes ankeedis terminit „keel“: Sõrve keel.

\subsection{Jõhvi vastused}

Jõhvi vastuseid oli 23. Enamik vastanuid oli pärit Jõhvist, aga ka KohtlaJärvelt ja Iisakust. Peaaegu poolte õpilaste (10) emakeel oli vene keel. Keskmiselt märgiti Jõhvis 2,5 traditsioonilist kohamurret või -murrakut ankeedi kohta standardhälbega 1,0. Kõik märgitud murded on esitatud tabelis 2 .

Enim märgitud murretest üsna lähedase osakaaluga olid saarte ja Võru murre. Jõhvi õpilased märkisid aga rohkem lääne- ja idamurret. Kaardil 3 on kujutatud need murdealad, mida vähemalt 15\% Jõhvi õpilastest märkis.

Saarte murde tuumala jääb vastuste põhjal Saaremaa keskele, hajudes Sõrve säärel. Võru murde tuum jaguneb Rõuge, Urvaste, Põlva, Kanepi ja Vastseliina kihelkonna vahel. Läänemurde tuum jääb Ridala, Martna, Noarootsi ja Lääne-Nigula kihelkonda. Idamurde tuum paikneb aga umbkaudu tervel Ida-Virumaal. Kaardil 4 on nende murdealade piirid vähemalt $50 \%$ üksmeele korral. 
Tabel 2. Jõhvi õpilaste märgitud murrete osakaal \%

\begin{tabular}{|l|c|}
\hline Murre & Osakaal \% \\
\hline Saarte & 59 \\
\hline Võru & 50 \\
\hline Ida- & 27 \\
\hline Lääne- & 18 \\
\hline Hiiu & 14 \\
\hline Setu & 9 \\
\hline Tartu & 9 \\
\hline Vene & 9 \\
\hline Kesk- & 5 \\
\hline Kihnu & 5 \\
\hline Ranniku- & 5 \\
\hline Muhu & 5 \\
\hline Mulgi & 5 \\
\hline Noarootsi & 5 \\
\hline Kagu- & 5 \\
\hline Ida-Virumaa & 5 \\
\hline
\end{tabular}

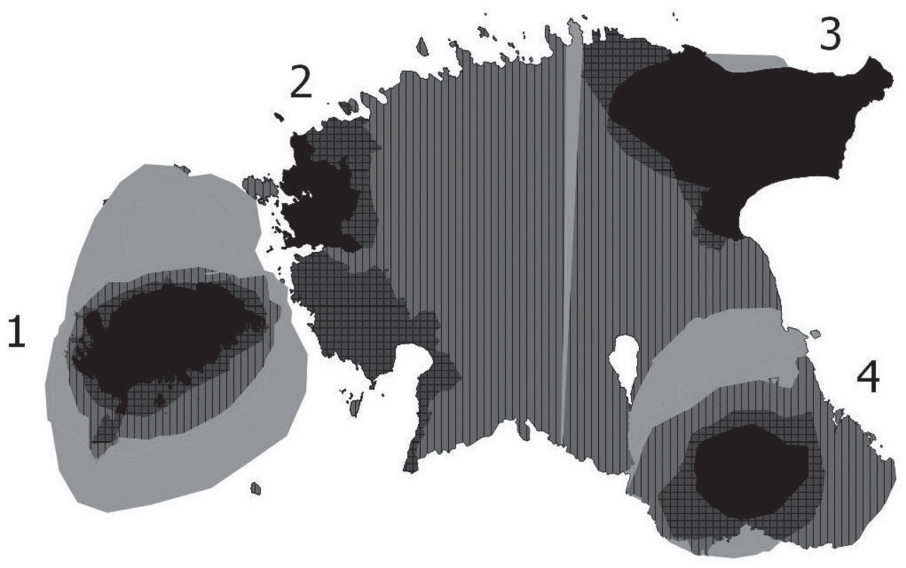

1. Saarte murre 2. Läänemurre 3. Idamurre 4 . Võru murre
$1-25 \%$
$1-25 \%$
$1-25 \%$
$1-25 \%$
ㅁIII $25-50 \%$
IIII 25-50\%
IIII 25-50\%
ㅁI|| 25-50\%
표 $50-75 \%$
- $50-75 \%$
- 50-75\%
$50-75 \%$
$75-100 \%$
$75-100 \%$
$75-100 \%$
$75-100 \%$

Kaart 3. Jõhvi õpilaste enim märgitud murrete ulatus \% 


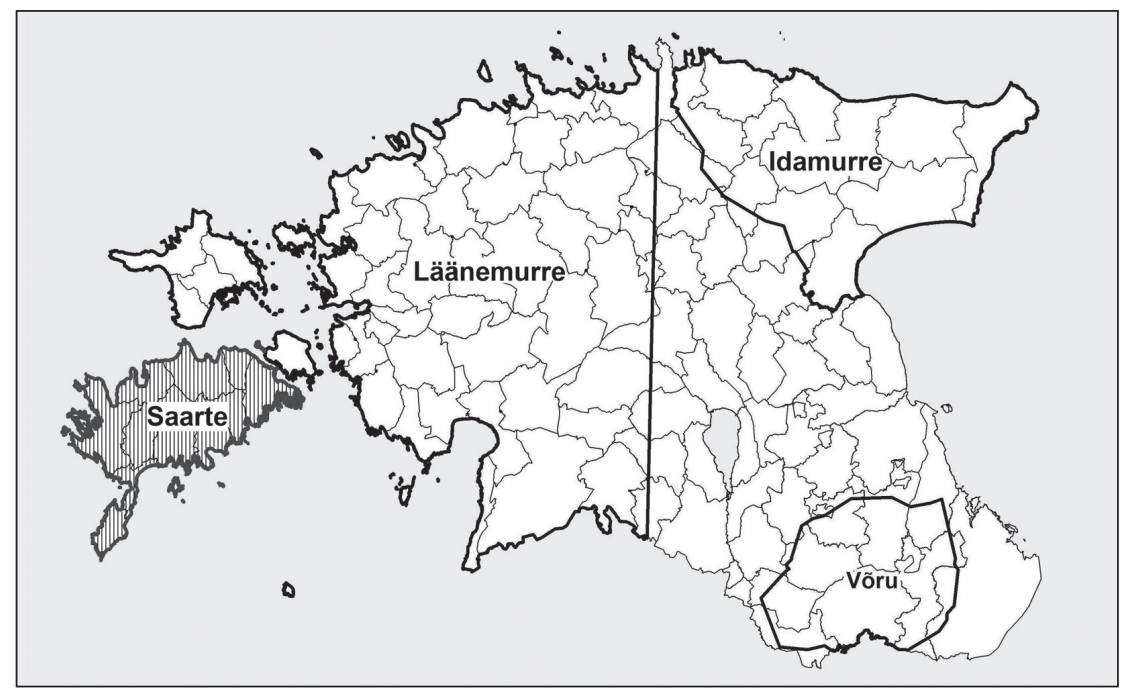

Kaart 4. Jõhvi õpilaste enim märgitud murded 50\% üksmeele korral

Kõige silmatorkavam erinevus kaartide 3 ja 4 vahel on vahest idamurde ulatus. Erinevus tuleneb kahest ankeedist, kus Eesti pind on umbes keskelt jaotatud lääne- ja idamurdeks. Kui võtta aluseks idamurde piirid kaardil 4, siis katab Jõhvi õpilaste märgitud idamurre umbes 44\% traditsioonilise idamurde alast. Märksa suurem osa õpilaste märgitud idamurdest jääb aga Lääne- ja Ida-Virumaale. Kuna umbes $72 \%$ protsenti Jõhvi õpilaste märgitud murdealast ei jää traditsioonilise idamurdeala alla, on põhjust oletada kas olulisi sisulisi muutusi või erinevusi terminoloogias. Traditsioonilisele idamurde piirkonnale lähedast ala iseloomustasid kaks õpilast kui regiooni, mida suuresti mõjutab vene keel.

Vastuste vähesuse ja mõne vastuse erandlikkuse tõttu ei muutu läänemurde paigutus kaardil 4 kuigivõrd kaardiga 3 võrreldes. Seetõttu hõlmab läänemurre ka näiteks Saaremaad ja Hiiumaad ning Kesk-Eestit ja põhjarannikut.

Samamoodi nagu Kuressaare vastustes hõlmab saarte murre vähemalt $50 \%$ seda märkinute arvates ainult Saaremaad. Hiiumaad peab saartemurdeliseks 10-20\% märkinutest, Muhu saart aga kuni 40\% märkinutest. Võru murre kaardil 4 katab umbes $76 \%$ traditsioonilisest ulatusest.

Jõhviski kasutas vaid üks õpilane murdeala nimetamisel maakonnanime. Sealsed õpilased kasutasid läbivalt terminit „,murre“. Saarte murret 
on ka Jõhvis valdavalt nimetatud ainsuslikult saare murdeks. Üks kord nimetati saarte murret isegi lihtsalt Saaremaa murdeks. Üks õpilane aga kasutas ka mitmuslikku vormi ning tähistas sellega nii Saare- kui ka Hiiumaal kõneldavat murret.

\subsection{Pärnu-Jaagupi vastused}

Pärnu-Jaagupi vastuseid oli 29. Vastanud olid enamasti pärit Halinga vallast, üksikud ka naabervaldadest. Emakeele kohta andmed puuduvad. Keskmiselt märkisid Pärnu-Jaagupi õpilased 2,8 traditsioonilist kohamurret või -murrakut ankeedi kohta standardhälbega 1,5. Kõik nimetatud murded koos osakaaluga on esitatud tabelis 3 .

Tabel 3. Pärnu-Jaagupi õpilaste märgitud murrete osakaal \%

\begin{tabular}{|l|c|}
\hline Murre & Osakaal \% \\
\hline Saarte & 69 \\
\hline Hiiu & 41 \\
\hline Kihnu & 41 \\
\hline Võru & 38 \\
\hline Setu & 14 \\
\hline Harjumaa & 10 \\
\hline Ida- & 7 \\
\hline Mulgi & 7 \\
\hline Pärnu/Pärnumaa & 7 \\
\hline Ida-Virumaa & 7 \\
\hline Kallaste & 3 \\
\hline Kesk- & 3 \\
\hline Lääne- & 3 \\
\hline Lääne-Virumaa & 3 \\
\hline Muhu & 3 \\
\hline Ruhnu & 3 \\
\hline Tallinna & 3 \\
\hline Vene & 3 \\
\hline Vormsi & 3 \\
\hline
\end{tabular}

Üle poole vastanutest märkis saarte murret. Peaaegu võrdse osakaaluga märgiti Hiiu ja Kihnu murrakut ning Võru murret. Murded, mida märkis vähemalt 15\% õpilastest, on kujutatud kaardil 5. 


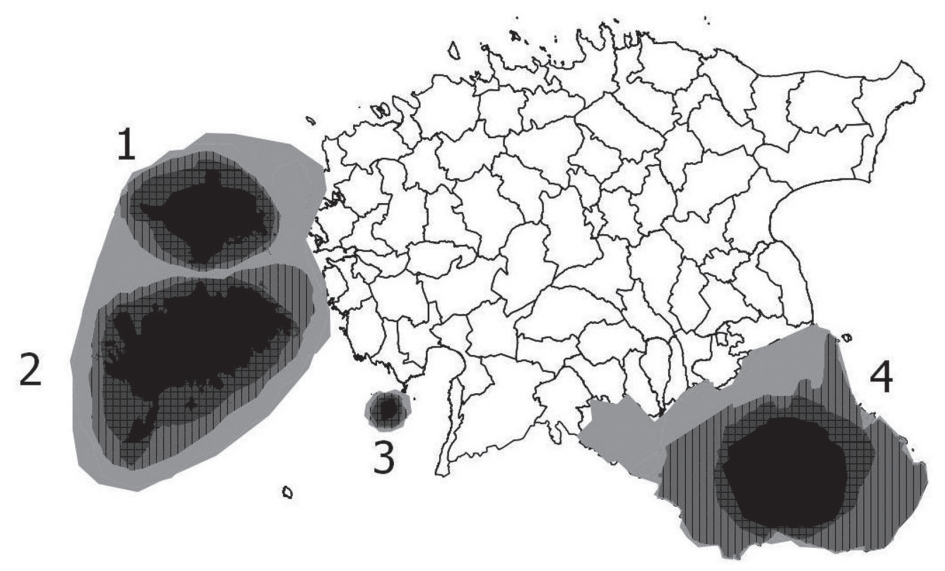

1. Hiiu murrak 2. Saarte murre 3. Kihnu murrak 4 . Võru murre
$1-25 \%$
$1-25 \%$
$1-25 \%$
$1-25 \%$
III $25-50 \%$
$50-75 \%$
IIIIII $25-50 \%$
IIIIII $25-50 \%$
IIIII $25-50 \%$
$75-100 \%$
- $50-75 \%$
世 $50-75 \%$
$75-100 \%$
프 $50-75 \%$
- $75-100 \%$

Kaart 5. Pärnu-Jaagupi õpilaste enim märgitud murrete ulatus \%

Saarte murde tuum jääb ka sel kaardil taas Saaremaa keskossa, ent hajub taas Sõrve säärel. Nii Hiiu kui ka Kihnu murraku tuum hõlmab tervet saart. Võru murde tuum jääb Rõuge, Urvaste, Põlva, Kanepi ja Vastseliina kihelkonda. Kaardil 6 on need murdealad kujutatud 50\% üksmeele korral.

Ka Pärnu-Jaagupi õpilaste märgitud saarte murdeala katab vaid Saaremaad. Kuni 10\% saarte murret märkinud õpilastest arvab aga, et ka Hiiumaal ja Vormsil kõneldakse saarte murret. Ligikaudu 30-40\% õpilastest peab ka Muhu saartemurdeliseks. Võru murdeala kaardil 6 kattub selle murde traditsioonilise alaga ligikaudu $71 \%$ ulatuses.

Neli õpilast nimetasid murdeid maakonna järgi. Saarte murret nimetati läbivalt ainsuslikult saare murdeks. Umbes $28 \%$ nimetas saart ka Saaremaa või saarlaste murdeks. Kaks õpilast kasutasid terminit „släng“, üks neist kujul „murre/släng“. Üks õpilane kasutas terminit „keel“: Võru keel. 


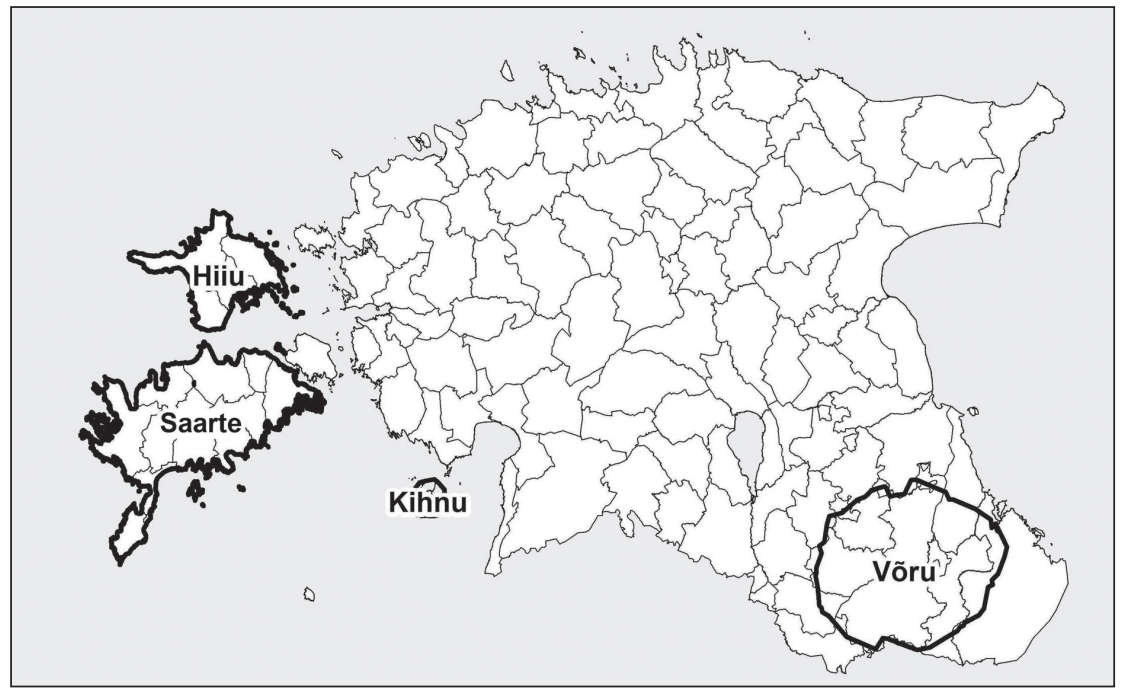

Kaart 6. Pärnu-Jaagupi õpilaste enim märgitud murded 50\% üksmeele korral

\subsection{Tartu vastused}

Tartu vastuseid oli 27. Enamik vastanuid oli pärit Tartu linnast või maakonnast. Õpilaste emakeele kohta andmed puuduvad. Keskmiselt märkisid Tartu õpilased 2,3 traditsioonilist kohamurret või -murrakut ankeedi kohta standardhälbega 1,3. Kõik murded, mida Tartu õpilased nimetasid, on koos osakaaluga esitatud tabelis 4 .

Tabel 4. Tartu õpilaste märgitud murrete osakaal \%

\begin{tabular}{|l|c|}
\hline Murre & Osakaal \% \\
\hline Võru & 70 \\
\hline Saarte & 59 \\
\hline Setu & 37 \\
\hline Mulgi & 15 \\
\hline Hiiu & 11 \\
\hline Kesk- & 7 \\
\hline Ranniku- & 7 \\
\hline
\end{tabular}




\begin{tabular}{|l|l|}
\hline Harju & 4 \\
\hline Liivi & 4 \\
\hline Lääne- & 4 \\
\hline Pärnu & 4 \\
\hline Ida- & 4 \\
\hline
\end{tabular}

Tartu õpilaste vastustes oli kolm murdeala, mida märkis vähemalt 15\% vastanutest: Võru, saarte ja Setu. Võru ja saarte murret märkis üle poole vastanutest. Kaardil 7 on kujutatud murded, mida märkis vähemalt 15\% õpilastest. Kuna Võru ja Setu murre suuresti kattusid, siis on Setu murre kujutatud eraldi kaardil 8.

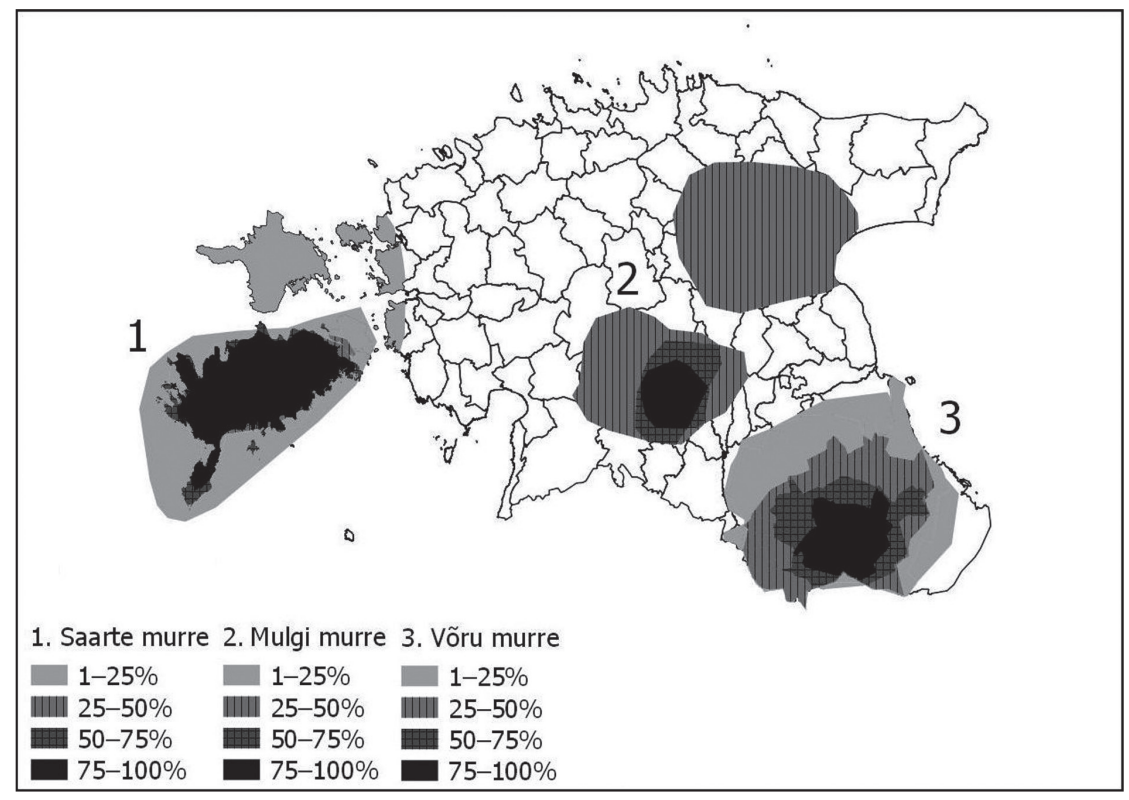

Kaart 7. Tartu õpilaste enim märgitud murrete ulatus \% 


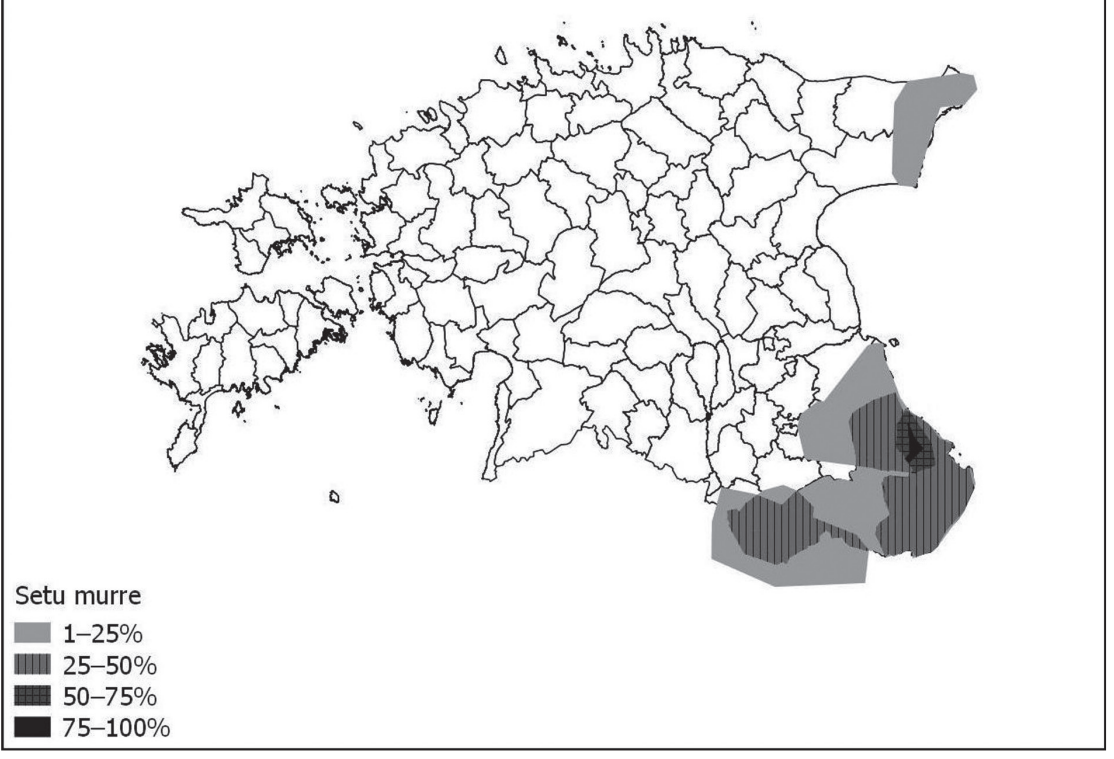

Kaart 8. Setu murde ulatus Tartu õpilaste vastustes \%

Võru murde tuum jääb Rõuge, Urvaste ja Põlva kihelkonda, Setu murde tuum aga enamjaolt Värska ümbrusesse. Mulgi murde tuum asub Viljandi, Paistu ja Tarvastu kihelkonnas. Üks õpilane märkis Mulgi murde ka Jõgevamaale. Saarte murde tuum on taas Saaremaa keskel, hajudes läänes ja Sõrve säärel. Kaardil 9 on kujutatud nende murrete ulatus 50\% üksmeele korral.

Kaardi 9 põhjal kõneldakse saarte murret vaid Saaremaal. 10-20\% vastanutest peab ka Hiiumaad saartemurdeliseks. 30-40\% õpilaste meelest on Muhugi saartemurdeline. Võru murdeala katab umbes $62 \%$ selle traditsioonilisest ulatusest. Setu murdeala katab ligikaudu 79\% selle traditsioonilisest ulatusest ning Mulgi murre kattub traditsioonilise Mulgi murdealaga umbes 23\% ulatuses. Nagu kaardil 9 näha, jaguneb Setu murre kaheks eraldi piirkonnaks: üks, mis paikneb Setumaal ja Värska ümbruses, ning teine, mis asub osalt Hargla ja Rõuge kihelkonnas. Kaardil 9 on samuti näha, et Võru ja Setu murre kattuvad vaid väga vähe. Kui mõlema murde puhul võtta arvesse kogu märgitud ulatus (nagu kaartidel 7 ja 8), siis Võru ja Setu murre ka kattuvad, kuid seda vähema hulga õpilaste arvates. 


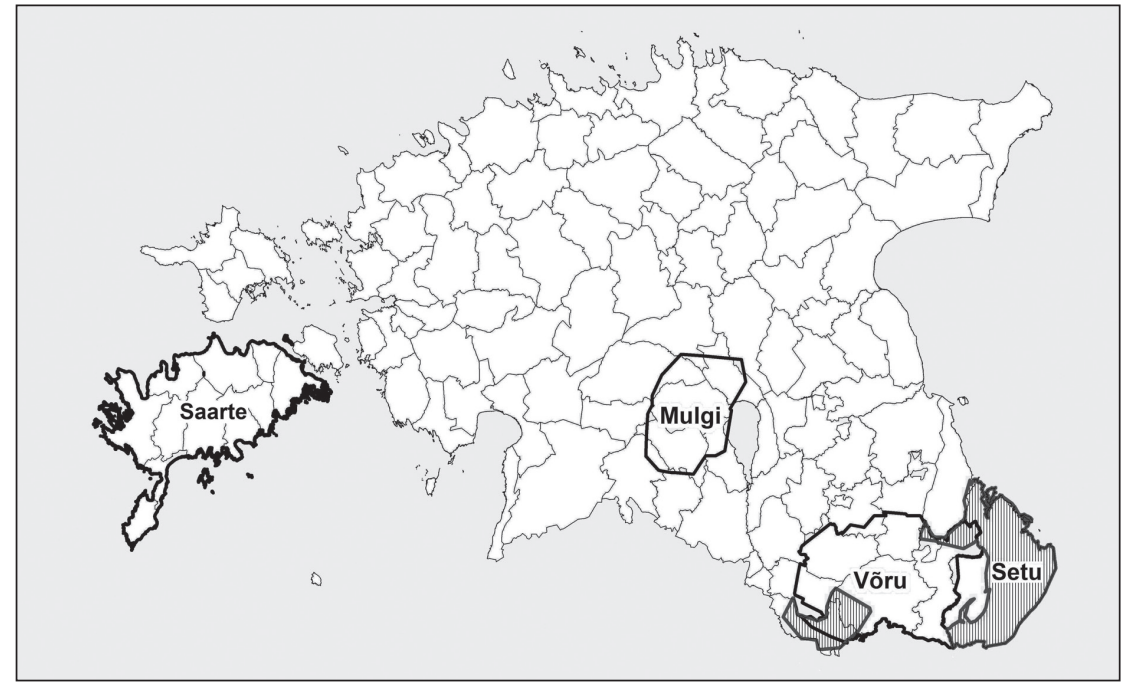

Kaart 9. Tartu õpilaste enim märgitud murded 50\% üksmeele korral

Kahel korral nimetati murret maakonna järgi (Ida-Viru ja Harju murre). Saarte murret nimetati läbivalt ainsuslikult saare murdeks. Umbes 30\% nimetas märgitud ala Saaremaa või saarlaste murdeks. Kaheksal korral kasutati terminit „murrak“: Liivi murrak, Mulgi murrak, Põhja-Eesti murrak, Pärnu murrak, Saare murrak, Saaremaa murrak, Setu murrak, Võru murrak.

\subsection{Võru vastused}

Võru vastuseid oli 35. Kõik vastanud olid pärit Võrust või Võrumaalt. Emakeele kohta andmed puuduvad. Keskmiselt märkisid Võru õpilased 3,7 traditsioonilist kohamurret või -murrakut ankeedi kohta standardhälbega 1,5. Tabelis 5 on esitatud kõik nimetatud murded koos osakaaluga.

Võru vastustes oli nimetatud viis sagedasemat murret. Kõige rohkem, üle kolmveerandi õpilastest märkis saarte ja Võru murret. Napilt alla poole vastanutest märkis läänemurret. Setu ja Mulgi murret märkis alla poole vastanutest. Kaardil 10 on kujutatud murded, mida märkisid vähemalt 15\% õpilastest. Kuna Setu (või Mulgi) murre ja Võru murre vastustes kattuvad, on parem Setu ja Mulgi murre esitada eraldi kaardil 11. 
Tabel 5. Võru õpilaste märgitud murrete osakaal \%

\begin{tabular}{|l|c|}
\hline Murre & Osakaal \% \\
\hline Saarte & 89 \\
\hline Võru & 77 \\
\hline Lääne- & 49 \\
\hline Setu & 46 \\
\hline Mulgi & 29 \\
\hline Ida- & 14 \\
\hline Kihnu & 9 \\
\hline Vene & 9 \\
\hline Tartu & 6 \\
\hline Viljandi & 6 \\
\hline Kagu-Eesti & 3 \\
\hline Kesk- & 3 \\
\hline Kirderanniku & 3 \\
\hline Peipsi & 3 \\
\hline Tallinna & 3 \\
\hline
\end{tabular}

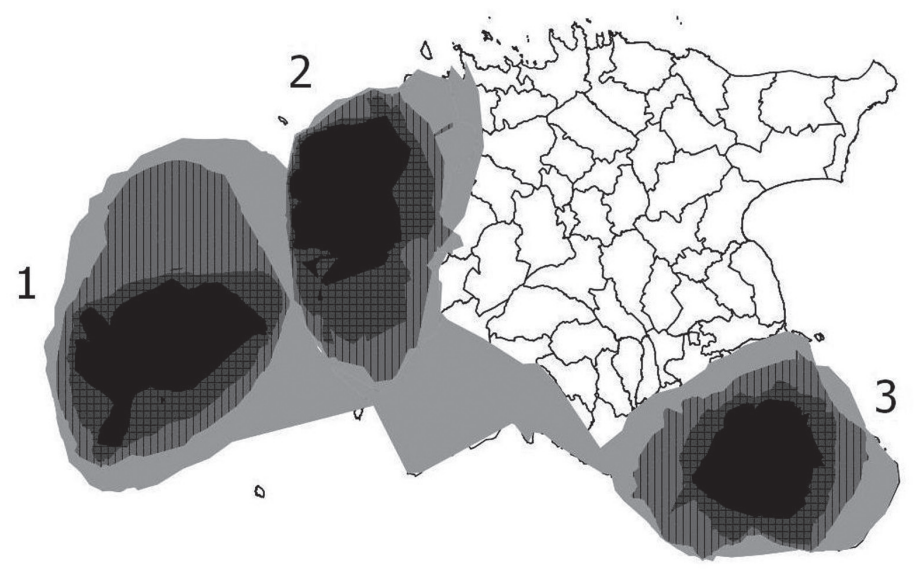

1. Saarte murre 2. Läänemurre 3 . Võru murre
$1-25 \%$
$1-25 \%$
$1-25 \%$
IIII $25-50 \%$
메II $25-50 \%$
IIIII $25-50 \%$
$50-75 \%$
표 50-75\%
표 $50-75 \%$
$75-100 \%$
75-100\%
$75-100 \%$

Kaart 10. Võru õpilaste enim märgitud murrete ulatus \% 


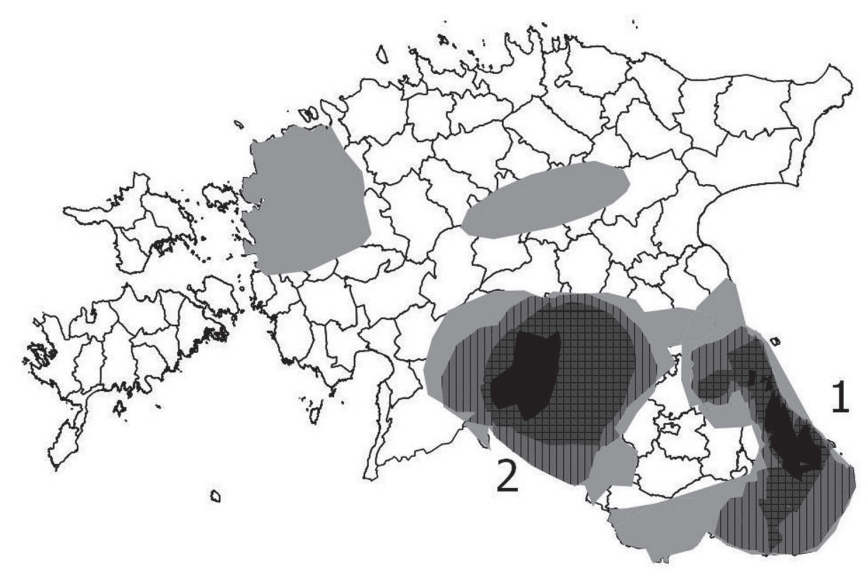

1. Setu murre 2 . Mulgi murre

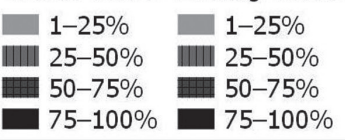

Kaart 11. Setu ja Mulgi murde ulatus Võru õpilaste vastustes \%

Nagu näha, on saarte murde tuumala Saaremaal. Läänemurde tuum on jaotunud Ridala, Martna, Kullamaa ja Risti kihelkonna vahel. Mulgi murde tuum jääb Paistu ja Viljandi kihelkonna alale. Paar õpilast märkis Mulgi murret ka Kesk- ja Loode-Eestisse. Võru murde tuumala jaguneb Põlva, Kanepi, Urvaste, Rõuge ja Räpina kihelkonna vahele. Setu murde tuum jääb Värska ja Mikitamäe ümbrusesse. Nende murrete ulatus 50\% üksmeele korral on kujutatud kaardil 12.

Kaardil 12 on näha, et Võru vastustes hõlmab saarte murdeala nii Saaremaad kui ka Muhumaad. Seega kattub Võru õpilaste märgitud saarte murdeala selle traditsioonilise alaga umbes $73 \%$ ulatuses. Läänemurdeala katab umbes $44 \%$ selle traditsioonilisest ulatusest ning Mulgi murdeala kattub traditsioonilise Mulgi murdealaga 68\% ulatuses. Võru murdeala katab 79\% selle traditsioonilisest ulatusest ning traditsiooniline Setu murdeala ja õpilaste märgitud ala kattuvad $89 \%$ ulatuses. Samuti saab täheldada, et lääne-, Mulgi ja Setu murre on õpilastel märgitud oluliselt põhja poole võrreldes keeleteadusliku liigendusega. 


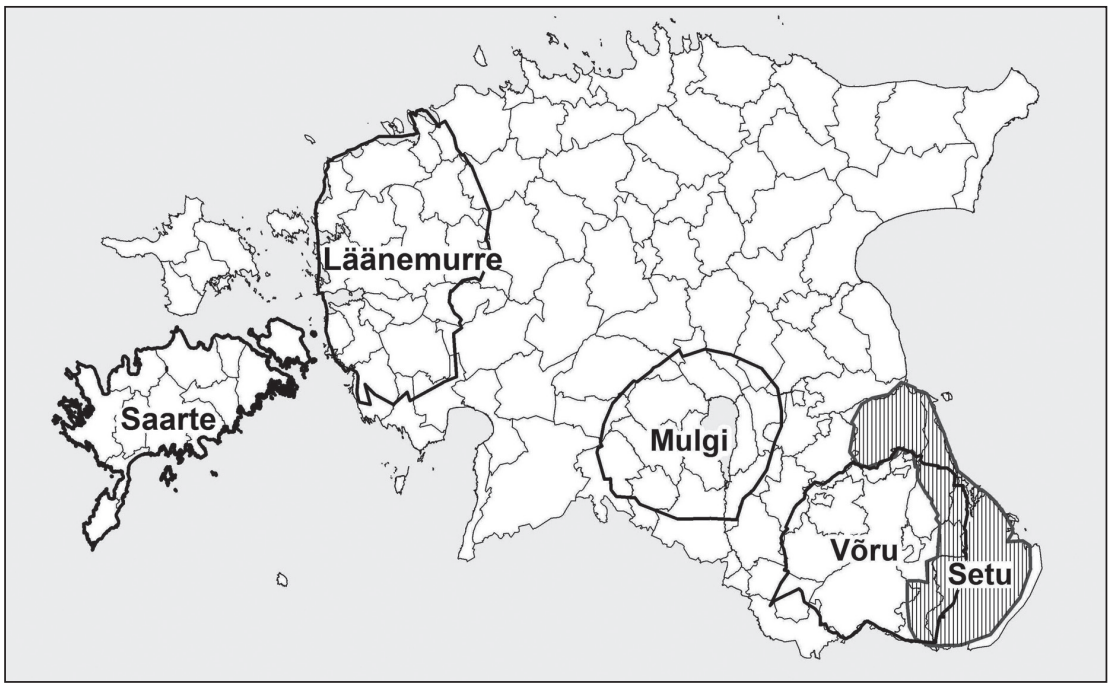

Kaart 12. Võru õpilaste enim märgitud murded 50\% üksmeele korral

Võru õpilased nimetasid kahel korral Viljandi murret. Kuna sama nime kannavad nii linn, makond kui ka kihelkond, pole võimalik eristada, mida õpilased seda märkides silmas pidasid. Kuna selle nimega märgitud ala oli suurem linnast ja kihelkonnast, võib oletada maakonna järgi märkimist. Ligikaudu 29\% saarte murret märkinud õpilastest kasutas murde nimetamisel mitmuslikku täiendit „saarte“. Enamasti (kuuel korral üheksast) märkisid õpilased sel puhul saartemurdeliseks nii Saare- kui ka Hiiumaa. Umbes 11\% nimetas saarte murret Saaremaa ja elanike (saarlaste) järgi ning märkis ainult selle saare. Üks õpilane kasutas terminit „,murrak“: Võru murrak, Setu murrak, Vene-Eesti segamurrak. Üks õpilane nimetas Võru ja Setu murret ka keeleks.

\subsection{Piirkondade võrdlus}

Üks uurimuse eesmärke oli võrrelda, kuidas piirkonniti murdetundmine erineb. Sellele on võimalik läheneda kaheti: võrrelda mitme piirkonna murdetaju omavahel või mingisuguse teistsugustelt alustelt tehtud liigendusega. Selles alapeatükis rakendan mõlemat. Niisiis võrdlen üldistatud kujutluskaarte ka viimatise murdeliigendusega (Pajusalu jt 2009). Seejuures ei ole eesmärk hinnata, vaid võrrelda, kuna üks liigendus ei ole 
teisest parem ega halvem. Üks peaks teist seega täiendama ja seletama keele geograafilist varieerumist teisest aspektist.

Esmalt tuleks võrrelda, kui mitut traditsioonilist kohamurret või -murrakut koos standardhälbega piirkonniti märgiti. Tulemused võtab kokku tabel 6.

Tabel 6. Märgitud traditsiooniliste kohamurrete keskmine hulk

\begin{tabular}{|l|c|c|}
\hline Piirkond & Keskmine & Standardhälve \\
\hline Kuressaare & 2,5 & 1,6 \\
\hline Jõhvi & 2,5 & 1 \\
\hline Pärnu-Jaagupi & 2,8 & 1,5 \\
\hline Tartu & 2,3 & 1,3 \\
\hline Võru & 3,7 & 1,5 \\
\hline
\end{tabular}

Tabelis esitatud tulemused näitavad, et piirkondade keskmised on vägagi ligilähedased. Erandlikud on vaid Võru vastused, kus märgiti keskmiselt märksa rohkem traditsioonilisi murdeid või murrakuid. Küllaltki lähedased on ka standardhälbed. Kõige väiksema hajuvusega on Jõhvi vastused. Kuigi Võru keskmine on märksa suurem, on standardhälve ligilähedane teistele piirkondadele. Seega märgiti Võrus murdeid või murrakuid rohkem ja vastused olid suuresti sama ühtlased kui mujal piirkondades.

Teiseks tuleks hinnata, mis murdeid või murrakuid igas piirkonnas kõige rohkem nimetati ning kuidas neid piiritleti. Uurimuse hüpotees oli, et mida kaugemal mingist murdealast õpilased elavad, seda vähem nad sellest teavad. Selle hüpoteesi näib aga kummutavat juba see, et iga piirkonna kaks enim märgitud murret olid saarte ja Võru. Laura Assmuthi (2005: 46) sõnul on saarlaste ja Saaremaa eripära säilimist põhjustanud peale geograafilise eraldatuse ka nõukogude võim, mis takistas liikumist saarele. Assmuthi sõnul on saarlus Saaremaa elanikele oluline ressurss, mille abil kohalikku elu arendada (kas või turismi kaudu) (Assmuth 2005: 47). Võru murde ja identiteedi säilimise ja edendamise eest on vahest rohkemgi hoolitsetud, olgu selle tõestuseks siis oma kirjakeel, ajaleht, keeleõpe koolides ja mõni muu keelekorralduslik meede või mainekujunduse tahk.

Olulisem murdenime tundmisest on aga see, kuivõrd on märgitud alad vastavuses murde traditsioonilise levilaga. Saarte murde kattuvus traditsioonilise alaga 50\% üksmeele korral oli kõigis piirkondades peale Võru ligilähedane 68\%-le. Võru õpilaste vastustes oli see aga $73 \%$, kuna 
ka Muhu peeti 50\% üksmeele korral saartemurdeliseks. Kui jääda vaid murdetasandile, siis järeldub, et kaugus ei ole saarte murdeala puhul määrav tegur. Samas on näha, et läänepoolsetes uurimispiirkondades Pärnu-Jaagupis ja Kuressaares - on rohkem õpilasi märkinud saarte murde murrakurühmasid: Hiiu, Muhu ja Kihnu ala. Seega murrakurühmade tasandil leiab piirkondlik hüpotees siiski kinnitust. Vastukäivate tulemuste põhjuseks on arvatavasti keeleteadlaste ja tavakõnelejate erinev terminoloogia ja liigendus.

Võru murde ulatus 50\% üksmeele korral oli piirkonniti veidi variatiivsem, seetõttu on otstarbekas see eraldi tabelina esitada (vt tabel 7).

Tabel 7. Piirkondades märgitud ja traditsioonilise Võru murdeala kattuvus \%

\begin{tabular}{|l|c|}
\hline Piirkond & Kattuvus traditsioonilise Võru murdealaga \% \\
\hline Kuressaare & 34 \\
\hline Jõhvi & 76 \\
\hline Pärnu-Jaagupi & 71 \\
\hline Tartu & 62 \\
\hline Võru & 79 \\
\hline
\end{tabular}

Kõige suurem erinevus on nähtavasti mandri ja saarte vahel: Kuressaare õpilaste märgitud Võru murdeala on 50\% üksmeele korral umbes 30-40\% väiksem. Siiski pole aga näha kauguse ja kattuvuse pöördvõrdelist seost: Võru ja Jõhvi õpilaste puhul on kattuvus ligilähedasem kui Võru ja Tartu puhul. Samuti jäi kõikide piirkondade Võru murde tuumala üldiselt samadesse kihelkondadesse. Seega ei saa väita siin hüpoteesi tõesust.

Kui jätta kõrvale saarte ja Võru murre kui murded, mille tundmist või tajumist kaugus kuigivõrd ei paista mõjutavat, võiks hüpoteesi kontrollimiseks analüüsida vastanute piirkondi teiste sagedasemate murdealade alusel. Piirkondade murdesagedustabeleid analüüsides hakkavad silma mitmed piirkondlikud erinevused. Juba eespool sai mainitud, et LääneEesti uurimispaikades (Kuressaare ja Pärnu-Jaagupi) märkisid õpilased rohkem erinevaid saarte murde murrakurühmi (Hiiu, Kihnu, Muhu). Tartus seevastu märgiti rohkem Setu ja Mulgi murret. Tähelepanuväärne on seegi, et Mulgi murde paigutamisel eksisid nii Tartu kui ka Võru õpilased. Kuigi neid oli vähe, on huvitav, et just selle Lõuna-Eesti murde paigutuse puhul tegid õpilased kõige rohkem vigu. Selle põhjust võib jällegi vaid 
ainult oletada (nt kas või see, et Mulgi nime ei leia ühestki tänapäevase haldusüksuse nimest, mistõttu puudub selgem orientiir). Jõhvis märgiti rohkem ida- ja läänemurret. Kuigi kõrvalekaldeid on (nt Võrus ja Jõhvis läänemurde märkimise osakaal), ei saagi loota täiuslikku kauguse ja teabe pöördvõrdelist suhet tänapäeval, mil info ja inimeste liikumine on võrdlemisi vaba, kiire ja lihtne. Seega on siiski silmatorkavad tendentsid eri piirkondade vastustes, mis näitavad, et lähedasemaid murdeid või murrakuid teatakse isegi rohkem ja paremini kui mõningaid eneseteadlikuma kõnelejaskonnaga murdeid.

Analüüsis on teisigi probleeme: kuidas analüüsida neid märgitud murdealasid, mille nimetus on küll sama mis traditsioonilisel murdealal, kuid mis suures osas omavahel kokku ei lange? Eeskätt puudutab see idamurret Jõhvi vastustes. On näha, et hulk Jõhvi õpilasi liigitavad end idamurde alla. See idamurre kattub aga pigem traditsioonilise kirderannikumurde alaga. Uute keeleandmete kogumine ja analüüsimine või ka lihtsalt täpsustuste küsimine võib seda kodeerimisprobleemi (kas liigitada idamurde või kirderannikumurde alla) hõlbustada. Selles analüüsis olen praegu lähtunud nimetamispõhimõttest: kodeeritud on siiski nimetuse, mitte maa-ala järgi.

Viimaseks tuleks analüüsida veel haldusüksuste mõju kujutluskaartidele. Maakonna järgi nimetati murdeid vähe (enamasti üks-kaks õpilast, kõige rohkem neli). Nendel puhkudel püüdsid õpilased suuremal või vähemal määral märkida maakonnale vastavat ala. Samuti ei märgitud iga kaardil olnud linna murdeks. See kinnitab Natalie Braberi (2015: 19-20) uuringu tulemust, mille järgi märgitakse kaardile ainult nende linnade keelekujusid, mis inimesel seostuvad murretega. Seega linnad katsekaardil ei juhata inimest, vaid on eelkõige abistavaks orientiiriks.

Kihelkonnapiiride järgimine vastustes erines piirkonniti rohkem. Kuressaares ei joonistanud täpselt mööda kihelkonnapiire ükski õpilane. Jõhvis joonistas mööda kihelkonnapiire umbes iga seitsmes õpilane, Tartus iga kolmas, Pärnu-Jaagupis umbes iga kuues ning Võrus iga seitsmes. Seega üldiselt õpilased ei järginud täpselt halduspiire, mistõttu võib järeldada, et haldus- ja murdepiiride vastavus pole enamiku jaoks selgelt vastavuses. 


\section{Kokkuvõte}

Kujutluskaartide katse eesmärk oli anda üldistav pilt sellest, kuidas inimene või inimrühm liigendab oma ümbritsevat keelemaastikku, lähtudes mingist kontseptsioonist (mis antud uurimuses on murre). Analüüsist selgus, et õpilaste elukoha kaugus murdealast mõjutab küllaltki palju seda, mida õpilased mingi murde kohta teavad, kuid ei näi päriselt kehtivat saarte ja Võru murde puhul. Need kaks olid igas piirkonnas enim märgitud murded, seega pärinevad õpilaste teadmised nende kohta mujalt kui ainult vahetust kokkupuutest. Nähtavasti on neil kahel murdel tugev teadvustatus Eesti ühtses info- ja kultuuriruumis. Õpilaste elukoht mõjutas nende murrete puhul aga seda, kuivõrd olid märgitud asend vastavuses nende murrete paiknemisega keeleteaduslikul murdekaardil. Võru murde asukoha märkimisel oli erinevus pigem Saaremaa ja mandriõpilaste vahel: Saaremaa õpilaste märgitud Võru murdeala oli üldiselt väiksem kui mandriõpilaste vastustes. Peaaegu iga piirkonna õpilased märkisid, et saarte murret kõneldakse vaid Saaremaal. Valdavalt märgitigi igale Lääne-Eesti saarele oma murre. Enamasti nimetati seda ainsuslikult saare murdeks, mistõttu tundub, et suuremal osal õpilastel ongi ainuvõimaliku saarte murde positsiooni omandanud Saaremaa. Ainult Võrus märkis rohkem õpilasi ka Muhu saartemurdeliseks.

Kui vaadata piirkondade teisi enim märgitud murdeid peale Võru ja saarte murde, siis tuleb elukoha mõju murdetajule selgemini ilmsiks. Nii näiteks märkisid Lääne-Eesti õpilased rohkem saarte murrakuid, Lõuna-Eesti õpilased aga Mulgi ja Setu murret ning Kirde-Eesti õpilased idamurret. Analüüsis ilmnesid mõned erinevused tava- ja teaduskeele mõistestikus: õpilased nähtavasti ei erista süsteemselt murdeid ja murrakuid; Jõhvi õpilased nimetasid oma kodumurret kirdemurde asemel ka idamurdeks.

Õpilaste kujutluskaardid erinesid keeleteaduslikust murdeliigendusest sellegi poolest, et enamasti ei püüdnud õpilased Eestit katta murdekontiinumiga: murded on justkui keelesaared ühiskeelse Eesti äärtes. Ühtpidi on see kujutluskaartide puhul tavaline, kuid niisamuti peegeldab see ikkagi ka praegust Eesti murdekeskkonda. 


\section{Kirjandus}

Antso, Siim 2015. Etnodialektoloogiline uurimus Eesti murdealadest. Magistritöö. Käsikiri Tartu Ülikooli eesti keele osakonnas.

Assmuth, Laura 2005. Meie ja „teised“: perifeeria identiteedid. - Piirikultuuriq ja -keeleq. Piirikultuurid ja keeled. Konvõrentś Kurgjärvel, 21.-23. rehekuu 2004. Toim. Karl Pajusalu, Jan Rahman. (= Võru Instituudi toimõndusõq 17.) Võro: Võro Instituut.

Bell, Scott, Jace Iong 2011. Sketch mapping and geographic knowledge: what role for drawing ability? - Understanding and Processing Sketch Maps. Proceedings of the COSIT 2011 workshop. Belfast, Maine, USA, September, 2011. Ed. Jia Wang, Klaus Broelemann, Malumbo Chipofya, Angela Schwering, Jan O. Wallgrün. (= IfGI prints 42.) Amsterdam: IOS Press.

Braber, Natalie 2015. Language perception in the East Midlands in England. Investigating East Midlands adolescents' perception of language variation in the UK. - English Today. The International Review of English Language 31 (1), 16-26. http://dx.doi.org/10.1017/S0266078414000509.

Dictionary = Dictionary of Human Geography. 2013. Ed. Noel Castree, Rob Kitchin, Alisdair Rogers. Oxford: Oxford University Press. http://dx.doi. org/10.1093/acref/9780199599868.001.0001.

Downs, Roger M., David Stea 1973. Cognitive maps and spatial behavior: process and products. - Image and Environment. Cognitive Mapping and Spatial Behavior. Ed. Roger M. Downs, David Stea. New Jersey: Transaction Publishers, 312-317.

Fought, Carmen 2002. California Students' Perceptions of, You Know, Regions and Dialects? - Handbook of Perceptual Dialectology. 2. Ed. Daniel Long, Dennis R. Preston. Amsterdam: John Benjamins, 117-136.

Ladegaard, Hans 2006. Review of Handbook of Perceptual Dialectology (Volume 2). - Journal of Multilingual and Multicultural Development 27 (2), 177-179.

Lameli jt 2008 = Alfred Lameli, Christoph Purschke, Roland Kehrein. Stimulus und Kognition. Zur Aktivierung mentaler Raumbilder. - Linguistik Online 35 (3), 55-86. http://www.linguistik-online.com/35_08/lameliEtAl.pdf.

Montgomery, Chris, Philipp Stoeckle 2013. Geographic information systems and perceptual dialectology: a method for processing draw-a-map data.Journal of Linguistic Geography 1 (1), 52-58.

Murray, Debra, Christopher Spencer 1979. Individual differences in the drawing of cognitive maps: the effects of geographical mobility, strength of mental imagery and basic graphic ability. - Transactions of the Institute of British Geographers 4 (3), 385-391. 
Niedzielski, Nancy A., Dennis R. Preston 2000. Folk Linguistics. (= Linguistics. Studies and Monographs 122.) Berlin, New York: Mouton de Gruyter. http://dx.doi.org/10.1515/9783110803389.

Pajusalu jt 2009 = Karl Pajusalu, Tiit Hennoste, Ellen Niit, Peeter Päll, Jüri Viikberg. Eesti murded ja kohanimed. 2., täiend. tr. Toim. Tiit Hennoste. Tartu Ülikooli eesti ja üldkeeleteaduse instituut, Eesti keele Instituut. Tallinn: Eesti Keele Sihtasutus.

Preston, Dennis R. 1989. Perceptual Dialectology. Nonlinguists' Views of Areal Linguistics. (= Topics in Sociolinguistics 7.) Dordrecht: Foris Publications. http://dx.doi.org/10.1515/9783110871913.

Preston, Dennis R. 1999. Introduction. - Handbook of Perceptual Dialectology. 1. Ed. Dennis R. Preston. Amsterdam: John Benjamins, xxiii-xl. http:// dx.doi.org/10.1075/z.hpd1.

Saareste, Albert 1932. Eesti keeleala murdelisest liigendusest. - Eesti Keel $1-2,17-41$.

Suurna, Ranel, Eveli Sisas 2010. GIS ja kartograafia alused. Tallinn: Riiklik Eksami- ja Kvalifikatsioonikeskus. http://www.ekk.edu.ee/vvfiles/0/ GIS loeng.pdf.

Siim Antso

eesti ja üldkeeleteaduse instituut

Tartu Ülikool

Jakobi 2

51014 Tartu

siimants@gmail.com 


\title{
A study on the perception of Estonian dialects among students from five regions
}

\author{
SIIM ANTSO
}

The article examines the dialect perception of students from Kuressaare, Jõhvi, Pärnu-Jaagupi, Tartu and Võru. The data was collected with the draw-a-map task known from perceptual dialectology, specifically from the works of Dennis R. Preston. Students were asked to mark all the dialects they know on an Estonian contour map with parish outlines and the biggest cities. These mental maps allow the analysis of how a person (or a group of people) represents and organises the surrounding world. According to the hypothesis, the closer a person lives to a dialect area, the better he/she should know the boundaries. To analyse the mental maps, I used ArcGIS software similar to that used by Montgomery and Stoeckle (2013) and constructed aggregated mental maps.

The analysis of the mental maps experiment revealed that the students' residence actually does affect their percpetion of dialects, with the exception of the Võru and island dialects. The latter are probably better known because of their distinct local identity and presence in media. Nevertheless, differences can be found in the mapping of those two dialects. The Vorru dialect area marked by students from Saaremaa was generally smaller than the Võru dialect area marked by their inland counterparts. Most students from Võru tagged two islands (Saaremaa and Muhu) under the label island dialect, while students from other schools only marked one (Saaremaa).

When analysing other dialects that the students marked more often, local differences in the perception of dialects emerged more greatly. For example, students from western Estonia marked different island dialects more commonly than others. Similarly, students from southern and eastern Estonia marked the Mulgi and Setu dialects and the eastern dialects, respectively, more commonly.

Keywords: Estonian, dialectology, perceptual dialectology, sociolinguistics, mental maps 